\title{
KEEFEKTIFAN MODEL PEMBELAJARAN TEBAK KATA TERHADAP HASIL BELAJAR PADA TEMA 7 "INDAHNYA KERAGAMAN DI NEGERIKU" SISWA KELAS IV
}

\author{
Muhammad Hanif Mukhlas \\ Fakultas IImu Pendidikan Program Studi Pendidikan Guru Sekolah Dasar \\ Universitas Pgri Semarang \\ e-mail: hanifmukhlas@gmail.com
}

\begin{abstract}
Abstrak
Jenis penelitian ini adalah penelitian eksperimen. Desain penelitian ini adalah One Group Pre Test and Post Test. Data penelitian ini berupa hasil belajar siswa kelas IV SD $\mathrm{N} 01$ Wonorejo Kabupaten Pekalongan yang berjumlah 20 siswa yang dianalisis dengan menggunakan rumus uji t. Berdasarkan hasil penelitian dapat disimpulkan bahwa berdasarkan hasil perhitungan uji $t$ diperoleh thitung $=2,678$. Dari daftar distribusi t dengan $\mathrm{dk}=\mathrm{n}-1=20-1=19$ diperoleh 2,09. Karena 2,678 $>2,09$ maka Ho ditolak, sehingga dapat disimpulkan bahwa ada keefektifan model pembelajaran tebak kata terhadap hasil belajar pada materi "Keanekaragaman di Negeriku" siswa kelas IV di SD N 01 Wonorejo Kabupaten Pekalongan. Saran yang dapat diambil dalam penelitian ini adalah supaya model pembelajaran tebak kata dapat digunakan sebagai salah satu alternatif guru dalam mengajar. Penggunaan media pembelajaran yang inovatif diharapkan dapat meningkatkan hasil belajar siswa.
\end{abstract}

Kata Kunci: Think Pair Share, Animasi Interaktif dan Hasil Belajar.

\begin{abstract}
This type of research is experimental research. The design of this study was One Group Pre Test and Post Test. The research data is in the form of learning outcomes of fourth grade students of SD N 01 Wonorejo in Pekalongan Regency, amounting to 20 students which were analyzed using the $t$ test formula. Based on the results of the study it can be concluded that based on the results of the calculation of the $t$ test obtained tcount $=2.678$. From the distribution list $t$ with $\mathrm{dk}=$ $n-1=20-1=19$ obtained 2.09. Because 2,678>2.09, Ho is rejected, so it can be concluded that there is effectiveness in the word guessing learning model on learning outcomes in the material "Diversity in My Country" of grade IV students at SD N 01 Wonorejo, Pekalongan Regency. Suggestions that can be taken in this study are so that the learning model guesses words can be used as an alternative teacher in teaching. The use of innovative learning media is expected to improve student learning outcomes.
\end{abstract}

Keywords: Think Pair Share, Interactive Animation and Learning Outcomes. 


\section{Pendahuluan}

Belajar adalah tindakan dan perilaku siswa yang kompleks. Proses belajar terjadi pada siswa untuk memperoleh sesuatu yang ada di lingkungan sekitar (Dimyati dan Mudjiono, 2009: 7). Proses belajar semata-mata bukan kegiatan menghafal. Banyak hal yang siswa ingat akan hilang dalam beberapa jam. Untuk mengingat apa yang telah diajarkan, siswa harus mengolahnya atau memahaminya. Proses belajar dan perubahan merupakan bukti hasil yang diproses. Belajar tidak hanya mempelajari mata pelajaran, tetapi juga penyusunan, kebiasaan, persepsi, kesenangan atau minat, penyesuaian sosial, bermacam-macam keterampilan lain, dan cita-cita. Dengan demikian, seseorang dikatakan belajar apabila terjadi perubahan pada dirinya akibat adanya latihan dan pengalaman melalui interaksi dengan lingkungan. Belajar dapat membuat perubahan perilaku secara kompleks baik perilaku maupun pencapaian tujuan belajar.

Berdasarkan hasil observasi pada siswa kelas IV di SD N 01 Wonorejo Kabupaten Pekalongan ditemukan bahwa pada pembelajaran tema 7 "Indahnya Keragaman di Negeriku" masih ada siswa yang belum memahami materi. Data hasil belajar ditunjukkan dengan nilai terendah 61 dan nilai tertinggi 86, dengan rata-rata nilai kelas 70,8. Siswa yang mencapai KKM sebanyak 24 siswa atau $60 \%$ dari 40 siswa yang mencapai tuntas belajar. Permasalahan pertama pembelajaran masih belum optimal karena pembelajaran yang dilakukan guru menonton dan kurang kreatif, sehingga siswa kurang aktif, cepat merasa bosan dan penggunaan media dan sumber belajar yang masih kurang. Permasalahan kedua, proses pembelajaran masih berpusat pada guru sehingga suasana pembelajaran belum memberikan kesempatan kepada siswa untuk mengemukakan gagasan.

Kurikulum 2013 adalah kurikulum yang berlaku dalam Sistem Pendidikan di Indonesia. Kurikulum 2013 ini merupakan kurikulum tetap diterapkan oleh pemerintah untuk menggantikan Kurikulum 2006 yang biasanya dikenal dengan kurikulum KTSP (Kurikulum Tingkat Satuan Pendidikan), kurikulum 2013 bertujuan untuk mempersiapkan peserta didik agar memiliki kemampuan hidup sebagai pribadi dan warga negara yang beriman, produktif, kreatif, inovatif, dan afektif serta mampu berkontribusi 1 pada kehidupan bermasyarakat, berbangsa, bernegara, dan peradaban dunia.

Pembelajaran dalam kurikulum 2013 khususnya jenjang sekolah dasar dari kelas 1 sampai dengan kelas 6 menggunakan pendekatan tematik integratif. Mata pelajaran dalam kurikulum 2013 diintegrasikan menjadi pokok bahasan menggunakan tema dan subtema. Dengan demikian, siswa diharapkan mampu memahami materi secara menyeluruh.

Pembelajaran pada sekolah dasar hendaklah memperhatikan berbagai aspek, karena anak pada usia SD memiliki karakteristik tersendiri yang harus dipahami oleh guru. Guru juga harus memahami perkembangan intelektual dan fungsi dari fisik peserta didik. Hal tersebut dimaksudkan agar tidak terjadi permasalahan dalam proses pembelajaran.

Berdasarkan kurikulum 2013, guru sebagai subjek pembelajaran, hendaknya guru dapat meningkatkan kemampuan kognitif serta keaktifan belajar siswa. Salah satunya adalah penggunaan model pembelajaran yang lebih bervariasi. Model pembelajaran yang dipandang mampu memberi harapan dan memperbaiki situasi belajar di sini adalah model kooperatif. Salah satu model kooperatif tersebut adalah model pembelajaran tebak kata.

Pembelajaran dengan model tebak kata adalah menebak suatu kata dengan cara menyebutkan kata-kata tertentu sampai kata yang disebutkan benar". Model tebak kata merupakan model pembelajaran yang berbasis permainan yang sesuai dengan karakter siswa sekolah dasar yang senang berman dan berkompetensi. Permainan tebak kata ini dimaksudkan untuk melatih siswa dalam mengingat dan menggunakan konsep yang telah dipelajari dan bahkan yang baru diketahui atau ditemukan pada saat permainan berlangsung, tanpa ragu atau takut salah, dan tentunya sekaligus melatih berbicara siswa dan bagaimana mengidentifikasikan sesuatu dengan membuat kalimat-kalimat (Said, 2015:95).

Penerapan model pembelajaran Tebak Kata ini diharapkan proses pembelajaran lebih menarik agar siswa menjadi berminat atau tertarik untuk belajar, mempermudah dalam 
menanamkan konsep-konsep dalam ingatan siswa. Selain itu siswa juga diarahkan untuk aktif, yaitu siswa atau peserta didik mampu dan dapat bertanya, mempertanyakan, dan mengemukakan gagasan.

Dari ulasan latar belakang tersebut di atas maka peneliti mengkaji melalui penelitian dengan judul "Keefektifan Model Pembelajaran Tebak Kata terhadap Hasil Belajar pada Tema 7 "Indahnya Keragaman di Negeriku" Siswa Kelas IV SD N 01 Wonorejo Kabupaten Pekalongan ".

\section{Metode}

Penelitian ini dilaksanakan pada semester II tahun ajaran 2017/2018 di kelas IV SD N 01 Wonorejo Kabupaten Pekalongan. Penelitian ini mengunakan pendekatan kuantitatif artinya hasil penelitian berupa angka. Penelitian ini merupakan penelitian eksperimen. Adapun tujuan dari penelitian ini adalah untuk menyelidiki adanya kemungkinan saling berhubungan sebabakibat dengan cara mengenakan kepada kelas sampel, kondisi perlakuan yang kemudian membandingkan hasilnya dengan pre test dan post test.

Populasi adalah keseluruhan subyek penelitian (Arikunto, 2006: 130). Populasi dalam penelitian ini adalah seluruh siswa III SD N 01 Wonorejo Kabupaten Pekalongan. Sampel adalah sebagian atau wakil populasi yang diteliti (Arikunto, 2006: 131). Sampel dalam penelitian ini kelas IV SD N 01 Wonorejo Kabupaten Pekalongan yang berjumlah 40 siswa, yang terdiri dari 28 siswa perempuan dan 12 siswa laki-laki.

Teknik sampling yang akan dilakukan dalam penelitian ini adalah dengan menggunakan cluster random sampling. Pengambilan sampel dilakukan secara acak pada populasi yang telah diuji normalitas dan homogenitas untuk memperoleh sampel yang normal dan homogen. Akan dipilih secara acak kelas yang akan digunakan sebagai kelas sampel dan kelas kontrol. Dalam penelitian ini peneliti mengambil 1 kelas sebagai kelas sampel, dan 1 kelas untuk uji coba. Pengambilan sampel dalam penelitian ini menggunakan teknik cluster random sampling, dengan alasan sebagai berikut. (a) Siswa yang menjadi objek penelitian duduk pada kelas yang sama, (b) Berasal dari lingkungan masyarakat yang sama sebab rata-rata siswa berasal dari daerah sekitar lokasi sekolah, (c) Mendapat perlakuan yang sama dalam pembelajaran IPA , (d) Pembagian kelasnya menggunakan sistem acak.

Variabel adalah obyek penelitian atau apa yang menjadi titik perhatian suatu penelitian. Variabel bebas adalah kondisi yang oleh pengeksperimen dimanipulasikan untuk menerangkan hubungannya dengan fenomena yang diobservasi. Variabel terikat adalah kondisi yang berubah ketika pengeksperimen mengintroduksi atau mengganti variabel (Arikunto, 2006: 118). Variabel dalam penelitian ini adalah Variabel treatment atau independent variabel yaitu variabel penyebab atau variabel yang mempengaruhi. Variabel bebas dalam penelitian ini adalah pendakatan pembelajaran yang digunakan. Dalam hal ini digunakan model tebak kata. Dan Variabel respon atau dependent variabel yaitu variabel akibat atau variabel yang dipengaruhi. Variabel terikat dalam penelitian ini adalah hasil belajar belajar siswa yang mendapat model pembelajaran tebak kata.

Desain penelitian dengan homogenitas dan normalitas untuk mengetahui sampel berada pada distribusi yang sama sehingga desain rancangan yang digunakan adalah One Group Pre Test and Post Test (Arikunto, 2007: 212). Desain pretest dan posttest group yakni:

Tabel 1. Desain Penelitian

\begin{tabular}{ccc}
\hline Pretest & Treatment & Posttest \\
\hline $\mathrm{O}_{1}$ & $\mathrm{X}$ & $\mathrm{O}_{2}$ \\
\hline
\end{tabular}

Keterangan

$\mathrm{O}_{1} \quad$ : Pembelajaran sebelum menggunakan model tebak kata (pretest)

$\mathrm{X} \quad$ : Model tebak kata

$\mathrm{O}_{2} \quad$ : Pembelajaran sesudah menggunakan model tebak kata 
Sikap belajar dinilai dengan menggunakan lembar observasi. Dengan `indikator ciri-ciri siswa yang mempunyai sikap belajar yang tinggi. Sikap belajar dihitung dengan menggunakan analisis deskriptif persentase, yaitu:

$$
\text { Persentase }(\%)=\frac{\text { jumlah skor yang diperoleh siswa }}{\text { jumlah seluruh skor }} \times 100 \%
$$

Siswa dapat mencapai sikap belajar mencapai nilai sikap 70 dengan kategori cukup (Sumber: SD Pedurungan 01 Semarang). Data yang diperoleh dari hasil belajar siswa dapat ditentukan ketuntasan belajarnya baik tuntas secara individu maupun tuntas secara klasikal.

Ketuntasan belajar individu dihitung dengan menggunakan analisis deskriptif persentase, yaitu:

$$
\text { Ketuntasan individu }=\frac{\text { skor yang diperoleh siswa }}{\text { skor maksimum }} \times \text { nilai maximum }
$$

Ketuntasan belajar klasikal dihitung dengan menggunakan analisis deskriptif persentase, yaitu :

$$
\text { Persentase }(\%)=\frac{\text { jumlah siswa yang tuntas belajar individu }}{\text { jumlah seluruh nilai }} \times 100 \%
$$

Keberhasilan kelas dilihat dari jumlah siswa yang mampu menyelesaikan atau mencapai minimal rata-rata 70 . Sekurang - kurangnya $85 \%$ dari jumlah siswa yang ada di kelas tersebut.

Analisis data merupakan suatu langkah yang sangat penting dalam keseluruhan penelitian. Data yang terkumpul akan diolah untuk mendapatkan suatu kesimpulan dari hasil penelitian. Agar data tersebut memberikan rangkuman keterangan yang dapat dipakai secara tepat dan teliti maka harus menggunakan teknik analisis data yang tepat.

Teknik analisis data merupakan salah satu cara yang digunakan untuk mengolah data penelitian guna memperoleh suatu kesimpulan. Dalam penelitian ini analisis data hasil eksperimen menggunakan pre-test dan post-test one group design. Rumus yang digunakan adalah t-test yang mana untuk mengetahui adanya efektivitas model NHT terhadap hasil belajar siswa. Adapun rumus t-test menurut Arikunto (2007: 306) adalah sebagai berikut:

Keterangan:

$$
t=\frac{M d}{\sqrt{\frac{\sum X^{2} d}{N(N-1)}}}
$$
$\mathrm{t}$
: Uji beda pre test dan post tes
Md $\quad$ : Mean dari perbedaan pretest dan posstest (posstest - pretest)
$\sum \mathrm{x}^{2} \mathrm{~d} \quad$ : Jumlah kuadrat deviasi
$N \quad$ : Jumlah subyek pada sampel

Apabila $t_{\text {hitung }}>t_{\text {tabel }}$, maka hipotesis kerja diterima sebaliknya jika $t_{\text {hitung }}<\mathrm{t}_{\text {tabel }}$ maka hipotesis ditolak dengan taraf signifikan $5 \%$.

\section{Hasil dan Pembahasan}

Penelitian ini dilaksanakan pada pengajaran tema 7 "Indahnya Keberagaman di Negeriku" sebelum menggunakan model pembelajaran Tebak Kata. Pembelajaran ini dengan menggunakan model pembelajaran ceramah. Guru hanya menyuruh siswa membaca materi. Guru menjelaskan materi kemudian siswa mengerjakan tes evaluasi.

Adapun distribusi frekuensi untuk masing-masing kategori hasil belajar dapat dibuat dalam tabel distribusi sebagai berikut : 
Tabel 2. Distribusi Frekuensi Hasil Belajar Pre Test

\begin{tabular}{|c|c|c|c|c|}
\hline Interval Nilai & Frekuensi & Kategori & Persentase & Keterangan \\
\hline $90-100$ & 1 & Sangat baik & 5 & \\
\hline $80-89$ & 2 & Baik & 10 & Tuntas \\
\hline $70-79$ & 11 & Cukup & 55 & \\
\hline $60-69$ & 6 & Kurang & 30 & Tidak Tuntas \\
\hline$\leq 59$ & & Sangat kurang & & Tluan tumas \\
\hline Jumlah & 20 & & $100 \%$ & \\
\hline Rata-rata & 71,750 & & & Cukup \\
\hline
\end{tabular}

Berdasarkan tabel di atas dapat diketahui data hasil belajar sebelum menggunakan model pembelajaran tebak kata dengan kategori sangat baik sebanyak 1 siswa atau $30 \%$, kategori baik sebanyak 2 siswa atau 55\%, kategori cukup sebanyak 11 siswa atau 2,5\% dan kategori kurang sebanyak 6 siswa atau 30\%. Dari tabel tersebut di atas maka dapat dibuat diagram batang data hasil belajar tema 7 "Indahnya Kebersamaan Negeriku" pada kelas pre test sebagai berikut:

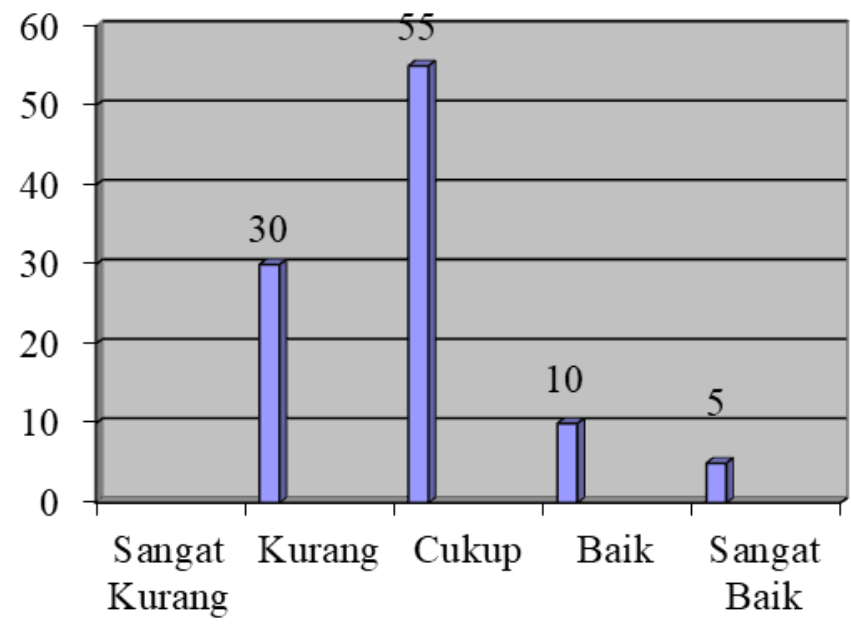

\section{Gambar 1. Diagram Batang Pre Test Hasil Belajar}

Rata-rata hasil belajar pre test sebesar 71,750 dalam interval 70-79 yang berarti termasuk kategori cukup. Deskripsi Data Hasil Belajar Tema 7 "Indahnya Kebersamaan di Negeriku" sesudah Menggunakan Model Pembelajaran Tebak Kata. Hasil belajar inilah yang kemudian dianalisis untuk mengetahui ada atau tidaknya perbedaan hasil belajar sebelum dan sesudah pembelajaran dengan menggunakan model tebak kata. Efektif atau tidaknya pembelajaran tema 7 "Indahnya Kebersamaan di Negeriku" menggunakan model pembelajaran tebak kata yang dilakukan ditinjau dari ketuntasan siswa belajar secara individu maupun klasikal. Adapun distribusi frekuensi untuk masing - masing kategori hasil belajar tema 7 "Indahnya Kebersamaan di Negeriku" dengan menggunakan model tebak kata dapat dibuat dalam tabel distribusi sebagai berikut :

Tabel 3. Distribusi Frekuensi Hasil Belajar Post Test

\begin{tabular}{lllll}
\hline Interval Nilai & Frekuensi & Kategori & Presentase & Keterangan \\
\hline $90-100$ & 3 & Sangat baik & 15 & \\
$80-89$ & 9 & Baik & 45 & Tuntas \\
$70-79$ & 6 & Cukup & 30 & \\
$60-69$ & 2 & Kurang & 10 & Tidak Tuntas \\
\hline
\end{tabular}




\begin{tabular}{lll}
\hline$\leq 59$ & \multicolumn{3}{c}{ Sangat kurang } \\
Jumlah & 20 & $100 \%$ \\
Rata-rata & 78,50 & \\
\hline
\end{tabular}

Berdasarkan tabel di atas dapat diketahui data hasil belajar post test dengan kategori sangat baik sebanyak 3 siswa atau 15\%, kategori baik sebanyak 9 siswa atau 45\%, kategori cukup sebanyak 6 siswa atau 30\% dan kategori kurang sebanyak 2 siswa atau 10. Dari tabel tersebut di atas maka dapat dibuat diagram batang data hasil belajar post test sebagai berikut:

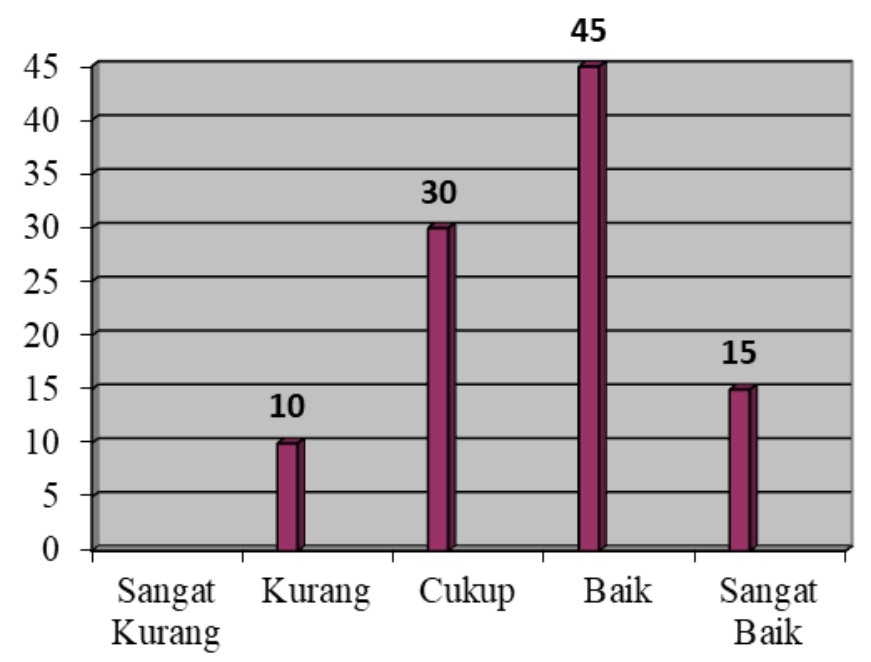

Gambar 2. Diagram Batang Hasil Belajar Post Test

Penelitian ini untuk mengetahui keefektifan model pembelajaran tebak kata pada siswa kelas IV di SD N 01 Wonorejo Kabupaten Pekalongan. Data diperoleh dari sebelum dan sesudah pembelajaran dengan menggunakan model pembelajaran tebak kata pada siswa kelas kelas IV di SD N 01 Wonorejo Kabupaten Pekalongan pada materi tema 7 "Indahnya Kebersamaan di Negeriku".

Data hasil belajar tema 7 "Indahnya Kebersamaan di Negeriku" sebelum menggunakan model pembelajaran tebak kata dengan kategori sangat baik sebanyak 1 siswa atau $30 \%$, kategori baik sebanyak 2 siswa atau 55\%, kategori cukup sebanyak 11 siswa atau 2,5\% dan kategori kurang sebanyak 6 siswa atau $30 \%$.

Data hasil belajar post test dengan kategori sangat baik sebanyak 3 siswa atau 15\%, kategori baik sebanyak 9 siswa atau 45\%, kategori cukup sebanyak 6 siswa atau 30\% dan kategori kurang sebanyak 2 siswa atau 10.

Rata-rata hasil pre test diperoleh sebesar 71,750 dalam interval $70-80$ yang berarti termasuk kategori cukup. Sedangkan, rata - rata hasil post test sebesar 78,500 dalam interval $70-80$ yang berarti termasuk kategori baik. Berdasarkan rata-rata di atas, dapat dibuat diagram batang sebagai berikut. 


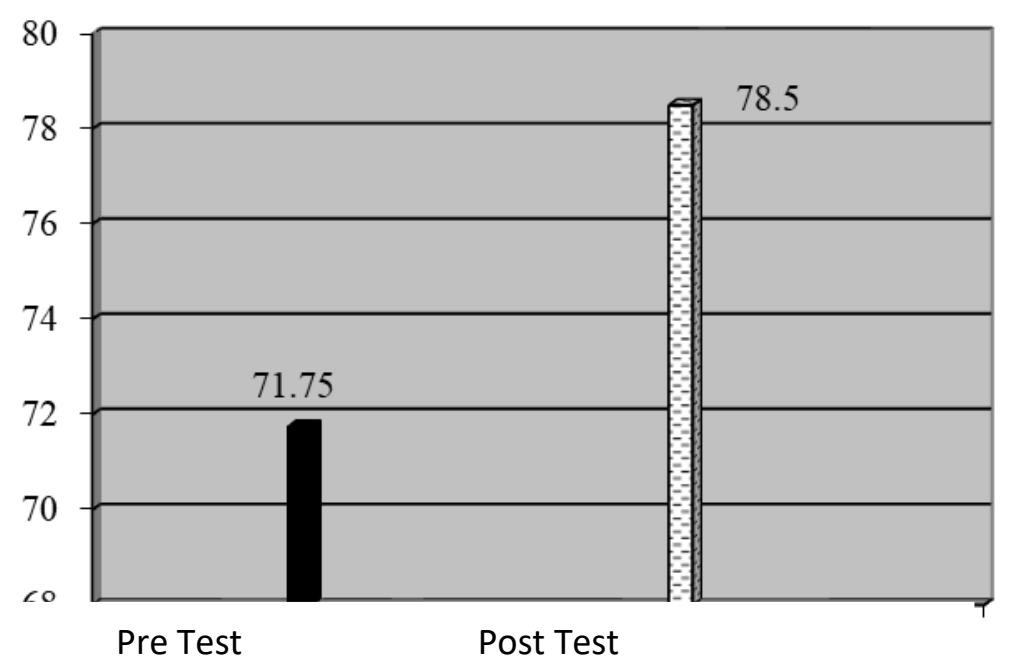

\section{Gambar 3. Diagram Batang Perbandingan Rata-rata Pre Test dan Post Test}

Uji hipotesis yang menyatakan pengaruh model pembelajaran tebak kata terhadap hasil belajar pada materi tema 7 "Indahnya Kebersamaan di Negeriku" siswa kelas IV di SD N 01 Wonorejo Kabupaten Pekalongan dilakukan dengan menggunakan teknik analisis efektivitas menggunakan rumus t-test. Dari hasil uji t diperoleh $t_{\text {hitung }}$ sebesar 2,678. Perolehan $t_{\text {hitung }}$ tersebut selanjutnya dibandingkan dengan $t_{\text {tabel. }}$ Harga $t$ hitung tersebut selanjutnya dibandingkan dengan $t_{\text {tabel }}$ dengan $\mathrm{N}=20$ untuk alpha $5 \%$ maka harga $t_{\text {tabel }}=2,09$. Ternyata harga $t$ hitung $>t$ tabel yaitu $>2,678>2,09$. Kesimpulannya adalah ada keefektifan model pembelajaran tebak kata terhadap hasil belajar pada materi "Keanekaragaman di Negeriku" siswa kelas IV di SD N 01 Wonorejo Kabupaten Pekalongan.

\section{Simpulan dan Saran}

Uji hipotesis yang menyatakan keefektifan model pembelajaran tebak kata terhadap hasil belajar pada materi tema 7 "Indahnya Kebersamaan di Negeriku" siswa kelas IV di SD N 01 Wonorejo Kabupaten Pekalongan adalah terbukti. Dari hasil uji t diperoleh thitung sebesar 2,678. Perolehan thitung tersebut selanjutnya dibandingkan dengan ttabel. Harga $t$ hitung tersebut selanjutnya dibandingkan dengan ttabel dengan $\mathrm{N}=20$ untuk alpha $5 \%$ maka harga $\mathrm{t}$ tabel $=2,09$. Ternyata harga t hitung $>t$ tabel yaitu $>2,678>2,09$.

Kriteria pengujian hipotesis adalah apabila thitung $>$ dari ttabel maka hipotesis diterima. Dengan demikian Ho ditolak dan Ha diterima. Kesimpulannya adalah ada keefektifan model pembelajaran tebak kata terhadap hasil belajar pada materi "Keanekaragaman di Negeriku" siswa kelas IV di SD N 01 Wonorejo Kabupaten Pekalongan.

Melihat dari kesimpulan berdasarkan pembahasan yang telah dipaparkan, penulis memberikan beberapa saran sebagai berikut: (1) Pembelajaran dengan model tebak kata memberikan pengaruh yang baik terhadap hasil belajar siswa, maka diharapkan guru mampu menerapkan pembelajaran dengan model tebak kata dalam proses belajar mengajar khususnya dalam pembelajaran di sekolah dasar, (2) Siswa agar dapat menerima model pembelajaran baru yang bertujuan lebih meningkatkan hasil belajar siswa.

\section{Daftar Pustaka}

Agus Suprijono. 2009. Cooperative Learning. Yogyakarta : Pustaka Belajar.

Anita Lie. 2004. Cooperative Learning. Jakarta: Grasindo.

Arikunto, S. 2002. Prosedur Penelitian Suatu Pendekatan Praktek. Jakarta: PT Rineka Cipta. 
Arikunto, S. 2006. Prosedur Penelitian Suatu Pendekatan Praktek. Jakarta: PT Rineka Cipta.

Dimyati dan Mujiono. 2009. Belajar dan pembelajaran. Jakarta: Rineka Cipta.

Djamarah, Syaiful Bahri dan Aswan Zain. 2006. Strategi Belajar Mengajar. Jakarta: Rineka Cipta.

Djamarah, Syaiful Bahri. 2008. Psikologi Belajar. Jakarta: PT Rineka Cipta.

Depdiknas. 2006. Peningkatan Kualitas Pembelajaran. Jakarta: Depdiknas.

Dimyati dan Mudjiono. 2009. Belajar dan Pembelajaran. Jakarta: PT Rineka Cipta.

Hamalik, Oemar. 2004. Psikologi Belajar dan Mengajar. Bandung: Sinar Baru Algensindo.

Hamdani. 2010. Strategi Belajar Mengajar. Bandung: Pustaka Setia.

Isjoni. 2011. Pembelajaran Kooperatif Meningkatkan Kecerdasan Komunikasi Antar Peserta Didik. Yogyakarta: Pustaka Pelajar.

Kurniasih, Imas. 2015.Model Pembelajaran.Jakarta: Kata Pena

Rusman. 2012. Model-model Pembelajaran Mengembangkan Profesionalisme Guru. Jakarta: PT. Raja Grafindo Persada.

Said, A. dan Budimanjaya. A. 2015. 95 Strategi Mengajar Multiple Intelligences. Jakarta : Prenada Media Group.

Slameto. 2010. Belajar dan Faktor-Faktor yang Mempengaruhinya. Jakarta : PT Rineka Cipta. Syah, Muhibbin. 2014. Psikologi Belajar. Jakarta: Rajawali Press.

Sudjana, N., 2009. Dasar-dasar Proses Belajar Mengajar. Bandung : Penerbit Sinar Baru Algesindo.

Suharso dan Retnaningsih. 2011. Kamus Besar Bahasa Indonesia. Jakarta: Rineka Cipta.

Sudjana. 2005. Matode Statistika. Bandung: Tarsito.

Sugiyono. 2006. Statistik Non Parametris untuk Penelitian. Bandung : CV. Alfabeta.

Thobroni, M. 2017. Belajar dan Pembelajaran: Teori dan Praktik. Yogyakarta: Ar-Ruzz Media.

Trianto. 2011. Model-model Pembelajaran Inovatif Berorientasi Konstruktivistik. Surabaya: Prestasi Pustaka Publisher. 